\title{
A DIGITAL SOLUTION TO HELPING THE ENVIRONMENT
}

\author{
Maria Jones ${ }^{1}$ \\ ${ }^{1}$ Affiliation not available
}

December 21, 2020

\begin{abstract}
Hosted file
helping-the-environment_earthrewards.pdf available at https://authorea.com/users/384229/ articles/499961-a-digital-solution-to-helping-the-environment
\end{abstract}

